\title{
STRATEGI GERAKAN PEREMPUAN (GREEN WOMAN) DALAM MELAWAN PENCEMARAN LINGKUNGAN OLEH INDUSTRI PENGELOLAAN LIMBAH B3 DI DESA LAKARDOWO KABUPATEN MOJOKERTO
}

\author{
Oleh: Aulia Izzah Azmi ${ }^{1}$, Aza Nur Alisa ${ }^{2}$, Fera Oktavia ${ }^{3}$ \\ ${ }^{1}$ Jurusan Sosiologi Universitas Brawijaya \\ ${ }^{2}$ Program Studi Ilmu Politik Universitas Brawijaya \\ ${ }^{3}$ Jurusan Sosiologi Universitas Brawijaya
}

\begin{abstract}
Abstrak
Konflik antara masyarakat Lakardowo dengan PT PRIA dalam kasus pengelolaan limbah B3 yang menyebabkan pencemaran lingkungan mengalami stagnasi. Hal ini memicu kekecewaan yang timbul dari masyarakat Desa Lakardowo terutama perempuan yang diakomodir oleh Gerakan Green Woman. Hal ini dikarenakan perusahaan tersebut mengelola limbah B3 dengan cara yang tidak tepat sehingga menyebabkan pencemaran lingkungan yang dampaknya sangat fatal seperti penyakit gatal-gatal dan gangguan pernapasan. Penelitian kualitatif-deskriptif ini mengkaji strategi gerakan Green Woman dalam memperjuangkan pemulihan lingkungan dan menuntut PT PRIA untuk mengelola limbah B3 agar lebih ramah lingkungan. Fenomena gerakan Green Woman ini dianalisis dengan menggunakan Identity Oriented Theory yang dikemukakan oleh Touraine. Tujuan dari penelitian ini adalah menjelaskan strategi yang disusun oleh kelompok perempuan yang tergabung dalam gerakan Green Woman Desa Lakardowo dalam melakukan gerakan sosial. Penelitian ini dilakukan dengan wawancara mendalam bersama masyarakat Desa Lakardowo dan aktivis Green Woman. Hasil penelitian ini menunjukkan bahwa optimalisasi jejaring sosial melalui media, mahasiswa, komunitas dan NGO menjadi faktor keberhasilan gerakan Green Woman di Desa Lakardowo. Selain itu, peran perempuan sebagai sentral dari ruang domestik yang sangat dekat dengan kebutuhan atas air menjadi motif dari terbangunnya kesadaran individu kelompok perempuan di Desa Lakardowo untuk mempertahankan gerakan Green Woman.
\end{abstract}

Kata Kunci: Green Woman, Limbah B3, Masyarakat Lakardowo, Perempuan.

\section{PENDAHULUAN}

Lingkungan merupakan salah satu ruang dimana manusia menjalankan aktivitasnya secara produktif. Aktivitas produktif masyarakat tentunya tidak lepas dari ketersediaan lingkungan yang nyaman untuk ditinggali dimana lingkungan yang nyaman akan menunjang proses beraktivitas secara produktif. Lingkungan hidup yang nyaman juga akan mempengaruhi aspek-aspek kehidupan masyarakat seperti aspek ekonomi, kesehatan, sosial dan budaya. Saat ini, modernisasi telah memasuki negara-negara berkembang, salah satunya Indonesia. Hal tersebut ditandai dengan masifnya perusahaan asing yang masuk dengan tujuan menanamkan modal di Indonesia. Dalam perjalanannya, hal ini menyebabkan banyaknya pembangunan industri swasta yang berlokasi di daerah perkotaan dan pedesaan. Modernisasi kehidupan manusia telah menyebabkan perubahan yang signifikan pada lingkungan (Nathanologi, 2018). 
Giddens membangun pengertian modernitas dalam bentuk juggernaut (Kurniawan, 2011). Bagi Giddens, modernitas dalam bentuk juggernaut dalah sesuatu yang sangat dinamis. Giddens menyebutnya sebagai dunia yang tidak terkendalikan, dengan peningkatan yang besar dalam kecepatan, ruang lingkup, dan perubahan mendalam melebihi sistem-sistem sebelumnya. Untuk membentuk argumennya, Giddens mendefinisikan modernitas dari segi empat lembaga utama. Pertama, kapitalisme dicirikan oleh produksi komoditas, kepemilikan pribadi atas modal, buruh yang diupah dan tidak memiliki harta benda. Kedua, industrialisme yang melibatkan manusia sebagai tenaga kerja yang hanya fokus pada pembagian kerja sesuai perannya menjadi pendukung terbentuknya modernitas. Pemenuhan kebutuhan manusia yang semakin bertambah dari hari ke hari tidak dapat dipisahkan dari pemanfaatan sumber daya alam. Dampaknya bukan hanya kerusakan terhadap lingkungan. Lebih jauh dari itu adalah krisis yang terjadi akibat dari memburuknya interaksi antara manusia dan lingkungan. Bahkan tidak jarang demi kepentingan beberapa pihak, lingkungan dieksploitasi sedemikian rupa dan menyebabkan kerugian bagi manusia.

Hal ini terjadi di Desa Lakardowo yang selama bertahun-tahun hidup dengan limbah pabrik medis yang menyebabkan berbagai kerugian pada masyarakat. Sejak berdirinya PT PRIA, warga Desa Lakardowo kerap menderita penyakit seperti gatalgatal, infeksi saluran pernafasan, batuk-batuk, hingga kerusakan paru-paru. Berdasarkan pendataan Organisasi Pendowo Bangkit, tercatat 342 warga terjangkit penyakit gatal-gatal dan gangguan pernapasan dalam kurun waktu 2017-2018. Penyakit-penyakit tersebut muncul sejak setahun sejak PT PRIA mendapatkan izin insinerator. Pada bulan Juli hingga Desember 2019, total warga yang sakit meningkat hingga 742 orang (Asnawi, 2020). Angka ini didapatkan dari data warga yang pergi berobat ke klinik kesehatan perusahaan. Data tersebut tidak termasuk data warga yang pergi ke puskesmas atau layanan kesehatan lain. Sejak PT PRIA didirikan, lingkungan disekitar warga tercemar. Salah satunya adalah air, sebagai sumber penghidupan warga sudah tidak layak digunakan lagi karena mengandung logam berat yang membahayakan bagi kesehatan. Pencemaran juga terjadi pada tanah dan hasil pertanian. Hasil penelitian sejumlah lembaga menyimpulkan ada kandungan logam berat cukup tinggi. Pada laporan berjudul The Environmental and Health Impact of PT PRIA Factory in Lakardowo menjelaskan bahwasanya, tanah di sekitar pabrik tercemar logam berat dengan konsentrasi 10 kali lipat dibanding titik kontrol. Hal ini dikarenakan adanya tumpukan debu yang mengendap dalam waktu yang cukup lama (Asnawi, 2020).

PT PRIA yang berdiri sejak tahun 2010 hingga 2013 dianggap sebagai perusahaan yang illegal, karena surat izin perusahaan baru dikeluarkan pada tahun 2014. Awal pendirian PT PRIA ini masyarakat Lakardowo tidak mengetahui bahwasannya perusahaan ini merupakan perusahaan penimbunan limbah B3 dan hanya diketahui bahwa PT PRIA merupakan perusahaan plastik dan batako. Dampak dari penimbunan limbah B3 mulai dirasakan oleh masyarakat Lakardowo 
dan beberapa dusun sekitar PT PRIA, sehingga muncul konflik yang terjadi antara PT PRIA dengan masyarakat Lakardowo. Pada tahun 2014, PT PRIA membuat surat pernyataan mengenai permohonan maaf dan perjanjian tidak akan melakukan penimbunan limbah B3 kembali, PT PRIA juga memberikan kompensasi kepada dusun yang terdampak oleh timbunan limbah B3 sebesar Rp. 25.000.000 per dusun. Hingga saat ini, dampak yang terjadi akibat adanya penimbunan limbah B3 oleh PT PRIA ini masih terus berlanjut yaitu kondisi air, tumbuhan, udara yang terkontaminasi oleh kandungan logam berat. Sehingga masyarakat Lakardowo tidak mendapatkan haknya sebagai masyarakat untuk dapat hidup dengan sehat karena tidak adanya keberpihakan antara Pemerintah dengan masyarakat Lakardowo dalam menangani konflik ini. Gugatan tidak diindahkan oleh pihak Pengadilan, hingga represifitas aparat terhadap aksi masyarakat. Akhirnya terjadi perlawanan yang masif oleh kelompok masyarakat Green Woman dan Pendowo Bangkit berupa penggugatan kasus ke jalur hukum dan melakukan strategi aksi yang masif hingga saat ini.

Konflik antara PT PRIA dengan Masyarakat Lakardowo sangat menarik untuk diteliti karena muncul gerakan sosial yang diakomodir oleh Masyarakat Perempuan di Daerah Lakardowo Kabupaten Mojokerto. Gerakan ini dinamakan Green Woman yang muncul karena adanya kesadaran masyarakat perempuan terhadap keberlangsungan kehidupan mereka kedepannya yang harus diperjuangkan khususnya pada ranah lingkungan karena timbunan limbah B3 ini berdampak langsung ke air, tumbuhan, maupun udara. Bagi para perempuan di Desa Lakardowo, perempuan adalah orang-orang yang paling dekat dengan lingkungan terutama pada pemanfaatan sumber daya untuk pemenuhan kebutuhan domestik. Apabila lingkungan telah tercemar, maka aktivitas manusia juga akan terganggu secara signifikan. Maka dari itu, perempun di Desa Lakardowo menghimpun massa untuk memperjuangkan keadilan bagi lingkungan mereka. Salah satu hal yang membuat penelitian ini menjadi lebih menarik untuk dibahas adalah bagaimana kemudian perempuan di Desa Lakardowo ini bisa mempertahankan gerakan yang mereka buat di tengah tanggung jawab domestik serta keterbatasan pengetahuan mengenai manajemen gerakan sosial. Walaupun Pemerintah sendiri nyatanya tidak mengakomodir konflik tersebut untuk berpihak kepada masyarakat, namun masyarakat Lakardowo khususnya masyarakat perempuan di Lakardowo ini tidak menyerah untuk memperjuangkan konflik PT PRIA yang telah menimbulkan dampak lingkungan yang cukup besar di Desa Lakardowo. Penelitian ini bertujuan untuk menganalisis mengenai strategi yang dilakukan oleh Masyarakat Perempuan di Lakardowo dalam memperjuangkan konflik antara PT PRIA dengan Masyarakat Lakardowo yang mengakibatkan dampak cukup besar di lingkungan Lakardowo hingga saat ini.

\section{METODE PENELITIAN}

Penelitian ini membahas mengenai strategi gerakan sosial yang diakomodir oleh masyarakat perempuan di Desa Lakardowo Kabupaten Mojokerto. Fokus penelitian ini membahas mengenai kondisi lapangan di wilayah Lakardowo akibat 
adanya perusahaan yang menimbun limbah B3, strategi pergerakan perempuan yang diakibatkan oleh ketidakpuasan masyarakat terhadap kebijakan Pemerintah, hingga terbentuknya Green Woman yang secara langsung diakomodir oleh seluruh masyarakat perempuan di Lakardowo Kabupaten Mojokerto. Penelitian ini menggunakan penelitian kualitatif-deskriptif dengan memanfaatkan metode studi literatur di bidang gerakan sosial. Pendekatan kualitatif adalah suatu proses penelitian dan pemahaman yang berdasarkan pada metodologi yang menyelidiki suatu fenomena sosial dan masalah manusia (Latour, 2019). Pada pendekatan ini peneliti membuat suatu gambaran kompleks, meneliti kata-kata, laporan terperinci dari pandangan responden, dan melakukan studi pada situasi yang alami (Creswell, 1998). Penelitian ini menggunakan dua sumber data yaitu sumber data primer yang dilaksanakan dengan wawancara di lapangan kepada narasumber yang berkaitan dengan permasalahan terhadap penolakan PT PRIA. Sumber data yang kedua yaitu sumber data sekunder yang berasal dari data jurnal, dokumen penting, literature, serta sumber informasi lain (Marc J. Ventresca, John W. Mohr, 2002).

Untuk memudahkan dalam menganalisis dan menyaring data maka para penulis menggunakan kata kunci gerakan sosial yang secara langsung diakomodir oleh masyarakat perempuan di Desa Lakardowo. Pengumpulan data tersebut dilakukan dengan menggunakan wawancara secara langsung di lapangan kepada narasumber yaitu Aktivis Green Woman, kemudian data yang diperoleh tersebut diolah dengan melaksanakan reduksi data, penyajian data, hingga penarikan kesimpulan. Penelitian ini menggunakan analisis data berupa transkrip data hasil wawancara dengan narasumber agar dapat melakukan kategorisasi yang relevan dengan fokus penelitian yang telah diambil sebelumnya. Selain analisis data berupa transkrip hasil wawancara, penulis juga menggunakan data sekunder berupa kombinasi data hasil wawancara narasumber dengan konsep maupun teori yang telah diambil dari literatur jurnal maupun buku. Sehingga data wawancara yang ada dapat relevan dengan fokus pembahasan selanjutnya.

\section{PEMBAHASAN}

Dalam upaya menutup industri PT PRIA yang mengakibatkan pencemaran lingkungan di Desa Lakardowo, terdapat strategi untuk memobilisasi gerakan sosial masyarakat Lakardowo. Namun fokus strategi gerakan tersebut dilandasi dengan semangat individu yang memperlihatkan peran identitasnya dalam membangun gerakan. Peneliti melakukan analisa fenomena tersebut menggunakan teori gerakan sosial berorientasi identitas yang dikemukakan oleh Alain Touraine. Dalam menilai sebuah gerakan sosial Alain Touraine menekankan pada pentingnya tindakan sosial, Touraine menjelaskan bahwa aksi yang dilakukan individu-individu dalam bentuk gerakan sosial merupakan suatu upaya untuk memproduksi dan mentransformasi struktur serta tatanan sosial yang ada (Rusmanto, 2013). Menurut Touraine sebuah gerakan sosial terbangun dari aksi sosial yang dianggap sebagai hal normal dari masyarakat untuk menggapai harapan menuju perubahan baik. 
Gerakan sosial dalam penelitian ini berupaya melihat orientasi identitas yang berusaha dibangun oleh kelompok perempuan melawan dari Desa Lakardowo yang mengidentitaskan kelompok mereka dengan sebutan “Green Woman”. Masyarakat Lakardowo menolak aktivitas industri pengolahan limbah B3 oleh PT PRIA sejak tahun 2013 dengan melakukan aksi di depan pabrik. Namun ketika itu masih ada masyarakat yang dimobilisasi tanpa mengetahui tujuan aksi secara pasti sehingga kesadaran individu untuk melawan belum sepenuhnya terbangun. Akan tetapi seiring berjalannya waktu masyarakat merasa mulai sadar bahwa keberadaan PT PRIA membawa dampak yang kurang baik untuk lingkungan Lakardowo karena terus melakukan penimbunan limbah B3. Masyarakat akhirnya melawan atas dasar kesadaran kolektif untuk menyelamatkan lingkungan dengan membentuk kelompok dengan nama Pendowo Bangkit yang merupakan singkatan dari Penduduk Lakardowo Bangkit sejak tanggal 20 Februari 2016 kemudian mulai menyusun strategi aksi agar dapat menghentikan aktivitas industri PT PRIA.

Analisis dari Alain Touraine memiliki kerangka penghubung yaitu antara pemahaman diri seseorang dengan ideologi yang tengah berkuasa di masyarakat kontemporer maupun gerakan sosial (Rusmanto, 2013). Untuk memeriksa penghubung antara dua elemen tersebut, Alain Touraine mengembangkan tiga tingkatan penyidikan. Pada penyidikan pertama Alain Touraine melakukan penyidikan dengan melihat bahwa gerakan sosial tersebut merupakan sebuah elaborasi dari representasi sosial, struktural masyarakat dan kultural masyarakat kontemporer. Pada penyidikan kedua, gerakan sosial memiliki sebuah penafsiran konflik dan memiliki tegangan yang terlibat dalam proses pencarian identitas manusia serta memiliki analisa dalam kerangka rujukan orientasi aksi. Pada penyidikan terakhir, Touraine menyadari bahwa dalam suatu gerakan sosial sangat penting setiap individu dalam gerakannya memiliki kesadaran individual sebagai ciri spesifik mahluk hidup. Dalam ketiga tingkatan penyidikan menurut Touraine tersebut, strategi aksi Green Woman dan Pendowo Bangkit justru disusun oleh kelompok perempuan karena perempuan-perempuan ini paling terdampak ketika lingkungannya tercemari oleh industri PT PRIA. Perempuan-perempuan mengidentitaskan diri sebagai kaum petani terdampak pencemaran limbah dari industri PT PRIA yang melakukan penimbunan B3. Selain menempuh jalur hukum, aksi yang pernah dilakukan tidak hanya di tingkat kabupaten atau DPRD saja, melainkan hingga melakukan aksi di depan gedung DPR, di Istana Merdeka, di depan Kantor Gubernur dan sudah pernah bertemu dengan staf presiden serta bertemu Ketua DLH tahun 2019.

Pada setiap aksi, Green Woman selalu mengidentitaskan diri sebagai kaum petani dengan menggunakan pakaian petani, membawa capil dan peralatan bertani, atau membawa patung padi berwarna hitam yang melambangkan tanaman padi yang sudah tercemar hingga warnanya hitam. Adapun aksi diam yang dilakukan dengan berduduk diam di depan gerbang gedung pemerintahan sejak pagi hingga jam 4 sore. Aksi diam tersebut merupakan salah satu strategi melawan dengan tuntutan bertemu 
gubernur dan dapat langsung mengemukakan protesnya kepada gubernur sehingga warga yang demo tidak kelelahan meski melakukan aksi dalam cuaca panas siang hari dan bertahan dari pagi hingga sore hari. Perempuan disini paling mendorong lakilaki dan bersatu tanpa memandang kelas karena sama-sama membutuhkan air dan tanah setiap harinya. Green Woman bersama pendowo bangkit berkomitmen untuk terus memperjuangkan lingkungan untuk anak cucunya meski belum ada hasil ataupun titik terang dari semua gugatannya. Sebagai penduduk Lakardowo, masyarakat ingin mempertahankan hak hidup mereka atas keselamatan lingkungannya yang tercemar akibat keberadaan baru industrialisasi PT PRIA.

Polleta dan Jasper (Francesca Polleta, James M. Jasper, 2001) merumuskan dengan faktor-faktor determinan terjadinya gerakan sosial, yaitu: identitas kolektif, solidaritas dan komitmen. Konsep-konsep turunan yang dirumuskan oleh Jasper dan polleta dapat digunakan untuk memahami teori ini. Salah satunya oleh Hunt dan Benford dalam (David A. Snow, Sarah A Soule, Hauspeter Kriesi, 2004) bahwa identitas kolektif dan konsep yang berkorelasi seperti solidaritas dan komitmen, merupakan penemuan yang sangat berdampak untuk memahami gerakan sosial. Karena identitas kolektif, solidaritas, dan komitmen dapat membantu menjawab pertanyaan-pertanyaan yang bersifat psikologis, dan sosiologi makro yang mempengaruhi terbentuknya gerakan sosial.

Identitas kolektif meliputi penekanan pada indikator komitmen individu, dan solidaritas kolektif, serta mengamati lebih luas mengenai struktur makrososial dan dinamika yang melampaui gerakan kolektivitas, termasuk yang mepengaruhi terbentuknya kepentingan bersama, konteks politik, simbol budaya, dan lain sebagainya. Agar tercipta kepemilikan kolektif atas suatu gerakan, maka harus ada perasaan solidaritas antar individu. Solidaritas antar individu akan muncul pada kondisi dimana identitas kolektif terjadi. Sementara, komitmen memfokuskan perhatian kepada investasi individu dalam garis aksi individu yang konsisten dengan garis aksi yang dimunculkan oleh kolektivitas. Komitmen membantu menjelaskan hubungan individu dengan kolektivitas melalui perhatian yang utama kepada aktivitas individu. Sedangkan, solidaritas memberikan perhatian kepada tingkat kohesivitas sosial yang muncul di dalam kelompok. Solidaritas digunakan untuk melakukan eksplorasi tentang hubungan individu dan kolektivitas dengan fokus utama pada kolektivitas.

Lingkungan yang menjadi sumber kehidupan masyarakat menjadi korban yang disebabkan oleh tidak optimalnya pengawasan pemerintah terhadap kegiatan operasional swasta. Kerusakan lingkungan yang dialami oleh masyarakat menimbulkan kekecewaan kolektif yang puncaknya menimbulkan perlawanan dengan tujuan menyelamatkan lingkungan yang telah mengalami kerusakan. Perlawanan yang didukung oleh jejaring sosial yang kuat, dan dimasifkan melalui simbol-simbol kultural dan aksi, maka politik perlawanan mengarah pada interaksi berkelanjutan dengan pihak oposisi dan menghasilkan gerakan sosial (Putra, 2006). 
Di Indonesia yang menganut demokrasi, individu memiliki hak untuk berpendapat di ranah publik. Hal ini menjadi peluang besar bagi individu maupun kelompok untuk mengekspresikan segala bentuk pemikiran melalui berbagai kegiatan. Gerakan sosial adalah sarana bagi kelompok masyarakat untuk mempengaruhi kebijakan pemerintah melalui arena politik (Klandersman, 2005).

Strategi gerakan Green Woman yang terdapat di Desa Lakardowo dapat dianalisa melalui tiga aspek. Pertama, aspek representasi sosial yang berbasiskan identitas kolektif. Gerakan sosial yang dimanifestasikan untuk menyuarakan ketertindasan dari masyarakat Lakardowo adalah gerakan perempuan yang bernama Green Woman. Gerakan ini lahir dari rahim ketertindasan perempuan di Lakardowo yang memiliki kesadaran bahwasanya lingkungan hidup mereka tengah terancam. Secara filosofis, alam dirujuk dalam metafora sebagai sesuatu yang feminin sehingga menjadi pijakan dalam membangun kerangka keterhubungan antara alam dan perempuan. Ambivalensi identitas antara perempuan dan alam berangkat dari posisi perempuan sebagai korban yang dieksploitasi secara berlebihan oleh laki-laki. Gerakan yang diusung oleh Green Woman untuk mempertahankan keselamatan lingkungan di Lakardowo merupakan manifestasi dari kesadaran seorang perempuan yang bertindak sebagai sekelompok individu yang paling dekat dengan alam (Candraningrum, Dewi dkk, 2014).

Kelompok perempuan di Lakardowo merupakan kelompok yang mempertahankan motivasi untuk melawan PT PRIA berdasarkan kedekatan mereka dengan alam. Ibu Sutamah, selaku pendiri dari gerakan Green Woman menegaskan bahwasanya kedekatan perempuan dengan alam didasari atas peran sentral perempuan atas ruang domestik. Contohnya, untuk pemenuhan kebutuhan makanan keluarga, perempuan membutuhkan air bersih untuk memasak. Perempuan adalah aktor yang mampu membangkitkan semangat untuk bergerak melalui perjuangan yang dilakukan di berbagai lini. Hal ini terlihat dari bagaimana anak-anak di Desa Lakardowo memiliki pemahaman yang komprehensif tentang kerusakan lingkungan yang dimana pemahaman tersebut didapatkan ketika melihat ibunya menggerakkan gerakan sosial. Salah satunya adalah anak Ibu Sutamah yang menggerakkan temanteman sebayanya untuk ikut membantu perjuangan para ibu dengan cara menulis surat secara kolektif yang ditujukan pada Gubernur Jawa Timur. Peran sentral perempuan, terutama Ibu di ranah domestik memegang andil besar dalam strategi bertahan sebuah gerakan sosial yang diinisiasi oleh perempuan.

Kedua, aspek penafsiran konflik. Gerakan sosial yang diakomodir oleh Green Woman di Lakardowo Kabupaten Mojokerto ini memperlihatkan dengan jelas bahwasannya terdapat represifitas oleh aparat saat aksi berlangsung. Represifitas tersebut terlihat pada tahun 2016, saat aksi dilaksanakan di wilayah Perusahaan PT PRIA masyarakat Lakardowo yang terlibat aksi tersebut ditangkap, diancam, hingga dipukul oleh aparat. Ancaman tersebut juga terjadi sebelum maupun sesudah aksi baik dari aparat secara langsung maupun dari pihak PT PRIA kepada masyarakat Lakardowo. Hal tersebut menjadi suatu hambatan dalam pelaksanaan gerakan sosial 
yang diakomodir secara langsung oleh Green Woman Lakardowo, pasalnya dengan timbulnya represifitas aparat tersebut menjadikan masyarakat tidak lagi percaya akan tugas aparat sebagai pengayom masyarakat dan cenderung berpihak kepada suatu kepentingan perusahaan. Hambatan selanjutnya yaitu tidak adanya dukungan dari pihak Pemerintah Desa maupun Provinsi terhadap gugatan yang dilakukan oleh Green Woman. Salah satu contoh ketidakberpihakan Pemerintah Desa maupun Provinsi tersebut terlihat ketika Pemerintah Provinsi memberikan solusi berupa Enkapsulasi terhadap 51 titik rumah warga yang terdampak timbunan limbah B3 yang pada awalnya Pihak Pemerintah Pusat yaitu DPR Komisi 7 memberikan solusi berupa Clean-Up terhadap 51 titik rumah warga, namun masyarakat jelas menolak solusi yang diberikan oleh Pemerintah Provinsi tersebut karena enkapsulasi sendiri sudah sangat jelas tidak dapat berpengaruh besar dalam mengatasi dampak penimbunan limbah B3 yang terjadi. Sehingga, Green Woman beserta Pendowo Bangkit ini cenderung bergerak secara mandiri hingga sekarang tanpa adanya dukungan dari Pemerintah Desa maupun Pemerintah Provinsi mulai dari strategi aksi yang dilakukan, gugatan yang dilayangkan kepada Bupati Mojokerto dan PT PRIA, hingga penelitian konflik oleh pihak luar selain masyarakat lakardowo seperti Mahasiswa, Dosen, dan Peneliti.

Ketiga, aspek kesadaran individual. Gerakan sosial di Desa Lakardowo tercipta dari tindakan individu dalam membuat keputusan tentang cara berinteraksi dengan lingkungan. Perempuan Lakardowo terutama yang tergabung dalam Green Woman telah memahami perubahan yang mungkin terjadi terhadap sistem sosial apabila mereka merespon gangguan terhadap lingkungan tempat tinggalnya. Mereka memiliki hak untuk menerima atau menolak perilaku terhadap lingkungan yang menguntungkan atau merugikan mereka. Pada tataran teori masyarakat Lakardowo belum menyadari peran aktor dalam membentuk sistem sosial tapi secara tidak langsung mereka sudah berupaya untuk menerapkan peran mereka dengan berupaya menolak pencemaran lingkungan yang dilakukan oleh PT PRIA. Seorang ahli antropologi dari Eropa yaitu Benyamin Orlove menekankan peran proses pengambilan keputusan di setiap individu dalam berinteraksi dengan lingkungan sekitarnya (Saharudin, 2007). Menurut Orlove perubahan terjadi karena adanya adaptasi lingkungan tercipta bukan sebagai akibat dari seleksi alam dalam tataran sosial budaya melainkan tercipta dari hasil keputusan bersama ribuan manusia tentang cara berinteraksi yang terbaik dengan lingkungannya.

Menurut Touraine sebuah gerakan sosial terbangun dari aksi sosial sebagai hal normal dari masyarakat untuk menggapai harapan menuju perubahan yang lebih baik. Akomodasi gerakan sosial oleh Green Woman merupakan sebuah perubahan yang muncul atas dasar kesadaran kolektif masyarakat Lakardowo. Hal ini didasari oleh kesadaran akan perlunya gerakan perempuan ini hadir di Lakardowo untuk menolak adanya PT PRIA, kesadaran tersebut muncul oleh inisiasi masyarakat perempuan Lakardowo untuk mendirikan perkumpulan masyarakat perempuan ini karena belum adanya perkumpulan yang diakomodir secara langsung oleh 
perempuan di Lakardowo dan hal tersebut akan menjadi sesuatu yang 'unik' serta patut untuk dipertahankan. Pada awalnya memang masyarakat laki-laki dan perempuan menjadi suatu perkumpulan yang sama. Namun, atas dasar inisiasi dari Ibu Sutamah untuk mendirikan suatu perkumpulan agar tidak diusir oleh preman PT PRIA ketika sedang berkumpul saat menyusun strategi sehingga muncul perkumpulan Green Woman yang diketuai oleh Ibu Sutamah dan perkumpulan Pendowo Bangkit yang diketuai oleh Bapak Nurasyim yang terdiri dari masyarakat laki-laki Lakardowo.

Tujuan kedua perkumpulan tersebut sama yaitu untuk melakukan aksi penolakan dan gugatan terhadap PT PRIA, dengan latar belakang Pendidikan yang dapat dikatakan rendah namun tekad dari seluruh masyarakat khususnya Green Woman sangatlah kuat. Hal tersebut juga didasari oleh rasa saling memiliki terhadap lingkungan, tanah, air, dan seisinya untuk warisan anak cucu Lakardowo di masa mendatang. Air, udara, tumbuhan, dan perekonomian menjadi suatu kebutuhan utama bagi para masyarakat Lakardowo dalam melakukan kehidupan sehari-hari. Sehingga hal tersebutlah yang memicu masyarakat perempuan di lakardowo untuk melakukan sebuah aksi Gerakan sosial dalam melakukan penolakan terhadap PT PRIA yang membawa dampak besar terhadap kehidupan sehari-hari masyarakat Lakardowo. Gerakan perempuan Green Woman ini menjadi sesuatu yang 'unik' di masyarakat khususnya di Lakardowo sendiri, pasalnya dari perkumpulan ini memiliki strategi yang cukup massif dalam melakukan aksi penolakan terhadap PT PRIA yang diakomodir oleh seluruh masyarakat perempuan di Desa Lakardowo, tidak terjadi pertikaian dengan Pendowo Bangkit walaupun sudah berbeda nama tetapi tetap memiliki tujuan dan misi yang sama kedepannya, serta rasa akan saling melindungi terhadap perempuan masyarakat Lakardowo ketika terjadi sesuatu hal yang tidak diinginkan.

Beavoir mendeskripsikan bahwasannya adanya kaum pria telah memposisikan diri mereka sebagai diri sendiri dan kaum perempuan sebagai orang lain (Hadi, 2017) . Dikotomi tersebut menghasilkan kaum perempuan seakan-akan berbeda dari pria dan lebih rendah. Penolakan yang dilakukan Beavoir dengan menyatakan bahwa perempuan itu tidak dilahirkan namun dikontruksi. Konsep Sartre dan Beauvior ini menjadi acuan bagi masyarakat perempuan di Lakardowo dalam melaksanakan gerakan sosial terhadap penolakan PT PRIA dengan menjadi dirinya sendiri. Pada dasarnya, masyarakat perempuan di Desa Lakardowo ini berusaha untuk setara dengan keberadaan laki-laki yang dapat mencipakan suatu gerakan tersendiri yang bernama Green Woman dan dapat memimpin suatu gerakan bagi dirinya sendiri. Keberadaan Pendowo Bangkit terhadap aksi gerakan ini juga ikut andil dalam mengakui keberadaan perempuan di Lakardowo dalam menginisiasi Gerakan Green Woman.

Oleh karena itu melakukan penolakan terhadap aktivitas pencemaran lingkungan merupakan hal yang memang sudah seharusnya dilakukan dan diperjuangkan. Suara dan penolakan yang diajukan oleh Green Woman sebagai 
kelompok yang paling terdampak memang sudah seharusnya diperjuangkan karena tidak memungkiri masih ada kemungkinan untuk dapat menyelamatkan lingkungan yang tercemar tersebut. Menurut Oberschall dalam Locher, keberhasilan dan kegagalan sebuah gerakan tergantung atas seberapa banyak orang-orang yang tergabung dalam organisasi (Jauhari, 2017). Keberhasilan Green Woman mungkin memang belum menunjukan hasil atau titik terang akan tetapi ketua dari Green Woman yaitu Ibu Sutamah mengatakan bahwa beliau dan masyarakat masih siap berjuang terus untuk penutupan perusahaan pengolahan limbah B3 PT PRIA agar lingkungan dapat terselamatkan dari pencemaran lingkungan demi keberlangsungan hidup anak cucu nanti. Perjuangan dengan terus mengajukan gugatan melalui jalur hukum dan menyusun strategi aksi masih terus dilakukan untuk mencapai keputusan bersama individu lain. Aktor yang berperan untuk memberikan keputusan dalam berinteraksi yang terbaik dengan lingkungan tidak hanya pemerintah, diperlukan juga aktor-aktor di luar pemerintah yang berjuang demi kepentingan atas terpenuhinya kebutuhan masyarakat terhadap kondisi lingkungan hidup yang baik dan seimbang (Wahyudin, 2018).

Green Woman masih memerlukan partisipasi dari Lembaga Swadaya Masyarakat (LSM) dan kesadaran seluruh masyarakat untuk bergerak bersama memperjuangkan penutupan PT PRIA agar tidak mencemari lingkungan Desa Lakardowo lebih parah lagi. Apabila masyarakat tetap diam menerima perlakuan perusahaan yang mencemari lingkungan tersebut terus beraktivitas, maka akan muncul perusahaan lainnya yang dengan berani mencemari lingkungan yang lainnya. Pencemaran tersebut juga dapat terus terjadi dan menyebar tidak hanya di Desa Lakardowo saja, melainkan dapat pula menyebar ke pemukiman sekitar dari Desa Lakardowo atau bisa lebih luas lagi. Saat ini juga sudah mulai dibangun perusahaan baru yang serupa dengan PT PRIA, yaitu pembangunan PT Jaka. Hal tersebut dapat membuktikan bahwa keputusan dari setiap individu sangat berpengaruh bagi lingkungan dan keberlangsungan hidup manusia kedepannya. Ketika pemerintah melindungi keberadaan PT PRIA maka akan muncul PT Jaka atau Perusahaan semacamnya yang lain. Setiap aktor berhak menentukan keputusan untuk berinteraksi dengan lingkungan, namun lingkungan juga menentukan keberlangsungan hidup manusia. Lingkungan dan manusia merupakan ekosistem yang saling bergantung satu sama lain. Akan tetapi keputusan para aktor akan menentukan keberlangsungan hidup lingkungan agar tidak tercemar dan ekosistem tetap seimbang. Apabila kita bandingkan aktor dalam pengambilan keputusan pihak perusahaan yang mencemari lingkungan tanpa rasa kasihan pada alam (air, tanah, udara, tanaman, dan sebagainya) yang dipertimbangkan hanyalah keuntungan pihaknya saja. Perusahaan semacam itu tidak mempertimbangkan kerusakan yang diciptakan dan dampak pada keberlangsungan hidup manusia di Bumi. Berbeda dengan perusahaan yang eksploitatif tersebut, perempuan di Lakardowo sebagai aktor memilih untuk berteman dengan lingkungan dan memperjuangkan keselamatan alam dari pencemaran limbah. 


\section{PENUTUP}

Dalam menyusun strategi aksi gerakan sosial oleh kelompok perempuan Desa Lakardowo yang disebut dengan Green Woman apabila dianalisis dengan teori berorientasi identitas yang dikemukakan oleh Alain Tourine. Terdapat 3 aspek yang mempengaruhi penyusunan strategi tersebut yaitu aspek representasi kelompok sosial, aspek penafsiran konflik dan aspek kesadaran individu. Pada aspek pertama kelompok sosial dalam penelitian ini adalah Green Woman selalu membawa atribut yang merepresentasikan bahwa mereka adalah kelompok tani atau kelompok yang berada dalam kelas menengah kebawah. Pada setiap aksi selalu membawa capil, alat bertani atau membawa patung padi berwarna hitam yang melambangkan tanaman yang tercemar. Dalam kelompok masyarakat Lakardowo, Perempuan adalah aktor yang mampu membangkitkan semangat untuk bergerak melalui perjuangan yang dilakukan di berbagai lini karena perempuan memiliki peran sentral dalam ranah domestik. Perempuan mendorong laki-laki dalam keluarga untuk memenuhi kehidupan sandang pangan utama yaitu kebutuhan air bersih dan perempuan sebagai ibu dapat memberikan pengertian kepada anak untuk ikut membantu berjuang dengan cara menulis surat untuk Gubernur Jawa Timur.

Kemudian pada aspek kedua yaitu penafsiran konflik, Green Woman memperlihatkan represifitas aparat maupun pemerintah ketika aksi dan aspek ketiga dengan keberadaan Green Woman dengan latar belakang Pendidikan yang dapat dikatakan rendah namun tekad dari seluruh masyarakat khususnya Green Woman sangatlah kuat untuk melakukan aksi penolakan dan gugatan terhadap PT PRIA. Hal tersebut juga didasari oleh rasa saling memiliki terhadap lingkungan, tanah, air, dan seisinya untuk warisan anak cucu Lakardowo di masa mendatang. Jadi meskipun pendidikan anggota Green Woman paling tinggi SMP, gerakan sosial mereka masih tetap bisa bertahan karena mereka memiliki peran sebagai sentral dari kehidupan domestik yang dekat dengan alam khususnya air. Namun hal yang terpenting adalah pemanfaatan jejaring, media, komunitas dan NGO yang menjadi kunci dari keberhasilan gerakan sosial dari Green Woman.

Setelah mengetahui motif dari munculnya kesadaran individu kelompok perempuan di Desa Lakardowo untuk membentuk gerakan Green Woman, maka hasil dari penelitian ini akan lebih maksimal apabila peneliti berikutnya akan meneliti tentang (1) pandangan pemerintah terhadap hubungan ekologi dengan ruang domestik masyarakat karena lingkungan dan ruang domestik sudah seharusnya saling berhubungan dan akan lebih maksimal lagi apabila peneliti berikutnya meneliti tentang (2) strategi pendampingan dari NGO atau LSM peduli lingkungan khususnya untuk perempuan di Desa Lakardowo mengingat perempuan yang melawan ini menempuh pendidikan maksimal SMP. Akan lebih baik apabila dapat diketahui cara pandang pemerintah dalam melihat pentingnya lingkungan bagi perempuan yang sentral di ruang domestik dan melihat realitas pendampingan LSM/NGO terhadap kelompok perempuan yang melakukan gerakan sosial karena identitas mereka yang sentral dalam ranah domestik. 


\section{DAFTAR PUSTAKA}

Asnawi. (2020, Oktober 25). mongabay.id. Retrieved Desember 22, 2020, from Nasib Warga Lakardowo, Satu Dasawarsa Hidup dengan Limbah Berbahaya: https://www.mongabay.co.id/2020/10/25/nasib-warga-lakardowo-satudasawarsa-hidup-dengan-limbah-berbahaya-1/

Candraningrum, Dewi dkk. (2014). Ekofeminisme II: Narasi Iman, Mitos, Air dan Tanah. Yogyakarta: Jalasutra.

Creswell, J. W. (1998). Qualitative Inquiry and Research Design: Choosing among Five Tradition. London: Sage Publications.

David A. Snow, Sarah A Soule, Hauspeter Kriesi. (2004). The Blackwell Companion to Social Movements. Oxford: Blackwell Publishing.

Francesca Polleta, James M. Jasper. (2001). Collective Identity and Social Movements. Annual Review of Sociology, 287.

Hadi, M. (2017). Melawan kekuasaan Laki-Laki: KAjian feminis Eksistensialis "Perempuan di Titik Nol" Karya Nawal e;-Saadawi. NUS A.

Jauhari, M. T. (2017). Gerakan Swakelola Purna TKI Dalam Meningkatkan Kesejahteraan Anggota (Studi Kasus Gerakan Organisasi Pertakina di Kabupaten Blitar). SKRIPSI, 1-110.

Klandersman, B. (2005). Protes dalam Kajian Psikologi Sosial. Yogyakarta: Pustka Pelajar.

Kurniawan, N. I. (2011). Melacak Pemikiran Anthony Giddens tentang Nation States dan Modernitas. Jurnal Ilmu Sosial dan Ilmu Politik Vol.4 No.3, 341-364.

Latour, B. (2019). A 'missing Family of Classical Orthogonal Polynomials. Journal of Chemical Information and Modeling, 53(9), 1689-1699.

Marc J. Ventresca, John W. Mohr. (2002). The Blackwell Companion to Organizations. New York: Blackwell Publishing Ltd.

Nathanologi. (2018). Modernitas Juggernaut Anthony Giddens. academia.edu, 20-30.

Putra, F. (2006). Gerakan Sosial: Konsep, Strategi,Aktor, Hambatan dan Tantangan Gerakan Sosial di Indonesia. Malang: Averroes Press.

Rusmanto, J. (2013). GERAKAN SOSLAL: Sejarah Perkembangan Teori Antara Kekuatan dan Kelemahannya. Sidoarjo: Zifatama Publishing.

Saharudin. (2007). Antropologi Ekologi. Bogor: Fakuktas Ekologi Manusia Bogor Press.

Wahyudin, E. A. (2018). Gerakan Sosial Baru dan Politik Lingkungan (Studi Atas Kontribusi WALHI Terhadap Ruang Terbuka Hijau di DKI Jakarta 20042017). Skripsi, 1-143. 